\title{
SUSTAINABLE PUBLIC PROCUREMENT: REALIZATION OF THE SOCIAL ASPECT IN REPUBLIC OF LITHUANIA
}

\author{
Virginijus KANAPINSKAS ${ }^{1}$, Žydrūnas PLYTNIKAS ${ }^{2}$, Agnè TVARONAVIČIENĖ $^{3}$
}

\author{
Mykolas Romeris University, Ateities g. 20, LT-08303 Vilnius, Lithuania

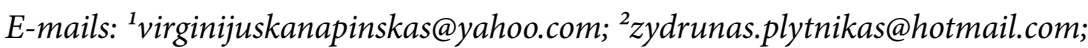 \\ 3a.tvaronaviciene@mruni.eu (corresponding author)
}

Received 4 May 2014; accepted 15 October 2014

\begin{abstract}
Public procurement concentrates large public sector's purchasing power, and has a significant impact on each country's economic development. The purpose of public procurement procedure is transparency, non-discrimination and accordance to the principles of fair competition in acquisition of goods, services and works necessary for the smooth functioning of the public administration. Besides, public procurement can be one of the most important instruments for sustainable development and other purposes useful to the whole society and the economy of the country. This article briefly discusses the concept of sustainable public procurement, reveals its main ideas and applications. One of them, the social sphere, was chosen the main object of the research. The possibility to decrease unemployment, to increase an integration of socially vulnerable group, and to achieve other socially-oriented goals through an effective implementation of the social aspect of sustainable public procurement has been illustrated. Thus, the article analyses the concept of social procurement, assesses the current situation in Lithuania, overviews the good practice of other countries and provides recommendations for measures to extend the application of socially oriented procurement.
\end{abstract}

Keywords: sustainable development, sustainable public procurement, socially oriented public procurement, social enterprise, qualification requirements, technical specifications, European Union regulation.

JEL Classification: K23.

\section{DARNIEJI VIEŠIEJI PIRKIMAI: SOCIALINIO ASPEKTO REALIZACIJA LIETUVOS RESPUBLIKOJE}

\author{
Virginijus Kanapinskas ${ }^{1}$, Žydrūnas Plytnikas ${ }^{2}$, Agnè Tvaronavičiené ${ }^{3}$
}

Mykolo Romerio universitetas, Ateities g. 20, LT-08303 Vilnius, Lietuva

El.paštas: ${ }^{1}$ virginijuskanapinskas@yahoo.com; ${ }^{2} z y d r u n a s . p l y t n i k a s @ h o t m a i l . c o m ;{ }^{3}$ a.tvaronaviciene@mruni.eu

Iteikta 201405 04; priimta 20141115

Santrauka. Viešieji pirkimai telkia didžiulę viešojo sektoriaus perkamąą galią ir daro didelę ịtaką kiekvienos valstybės ekonomikos vystymuisi. Viešųjų pirkimų procedūrų tikslas - laikantis skaidrumo, nediskriminavimo ir sąžiningos konkurencijos principų, įsigyti prekių, darbų ir paslaugų, reikalingų sklandžiam viešojo administravimo institucijų funkcionavimui. Be šio tikslo, viešieji pirkimai gali būti viena svarbiausių darniojo vystymosi koncepcijos ígyvendinimo priemonių, nes ją naudojant galima pasiekti visuomenei naudingų rezultatų. Šiame straipsnyje apžvelgiama darniųjų viešųų pirkimų koncepcija ir atskleidžiamos jos galimo pritaikymo sritys. Viena jų - socialinè sfera - pasirenkama svarbiausiu tyrimo objektu. Efektyviai

Copyright $\odot 2014$ The Authors. Published by VGTU Press.

This is an open-access article distributed under the terms of the Creative Commons Attribution-NonCommercial 4.0 (CC BY-NC 4.0) license, which permits unrestricted use, distribution, and reproduction in any medium, provided the original author and source are credited. The material cannot be used for commercial purposes.

To link to this article: http://dx.doi.org/10.3846/btp.2014.529 
taikant socialinį darniujų viešujų pirkimų aspektą galima sumažinti nedarbą, padidinti pažeidžiamiausių visuomenės grupių integracijos laipsnį ir pasiekti kitų socialiai orientuotų tikslų. Straipsnyje analizuojama socialinių pirkimų samprata ir ịvertinama esama situacija Lietuvos Respublikoje, pristatoma geroji užsienio šalių praktika ir pateikiamos rekomendacijos, kaip praplėsti socialiai orientuoto pirkimo taikymą.

Reikšminiai žodžiai: darnusis vystymasis, viešieji pirkimai, socialiniai pirkimai, socialinès įmonès, kvalifikacijos reikalavimai, techninès specifikacijos, Europos Sąjungos teisè.

\section{Introduction}

In 20th century, the dwindling natural resources, the growing scale of consumption of developed countries and increasingly overwhelming problems of poverty and hunger in developing countries forced the world to look back and assess the damage caused to the environment and social balance of the world community. In virtue of the United Nations initiatives, on a global scale the world's countries were invited to change the usual behaviour stereotypes and begin to follow the new ideology of social development, i.e. sustainable development, which is based on the elements that are obligatory for implementation at all facets of society: environmental protection, responsible social and economic development. The world step by step translated the objectives of sustainable development into national programming documents and legislation, and began to look for the appropriate legal and other social measures to implement these ideas (Tvaronavičienè 2012). Public procurement, by means of which states purchase goods, works and services needed to carry out the functions thereof, is recognized as one of the most important instruments of state policy (Brammer, Walker 2007; Thai 2001; McCrudden 2004; Medina-Arnaiz in 2010 and others), so while implementing the sustainable development concept in the world, it is also considered to be a suitable legal tool for the dissemination of sustainable development principles, which led to the development and wide application of the concept of sustainable public procurement.

It is noted that the sustainable public procurement is usually seen exclusively through the prism of the environment protection, sometimes as a stimulant of responsible and progressive economic growth, but sparsely in a social aspect. This element of sustainable development in the context of public procurement gets relatively little emphasis in academic researches. This confirms the need for a deeper analysis of this issue. Relevance of the topic is also revealed by the fact that the EU public procurement law (and thus the national law of the Member States) is in a constant process of change, and the effective evolution needs guidelines for direction for the development. Having developed the concept of socially-oriented purchases and disclosed applicability thereof, they are potentially capable to help countries to achieve better results in the creation of the welfare state. It should also be noted that many countries are looking for ways to engage the public sector to use more social criteria in public procurement. Systematised analysis of such possibilities have the potential to be widely applicable in practice.

Notably, despite the relevance and high practical applicability, the issue of public procurement as an implementation tool for social aspect of sustainable development has not been extensively analysed in scientific literature. The works of McCruden (2004, 2007 etc) should be noted as the most important in this field. In Lithuanian science, the social aspect of sustainable public procurement has been researched extremely little. Individual issues of social requirements in public procurement have been dealt with in a fragmentary way only (Soloveičikas 2009; Junevičius, Ereminaitè 2010; Palidauskaité, Ereminaitè 2010; Tvaronavičienè 2012). Given the relevance and novelty of the study, it is stipulated that in addition to the educational value, the theoretical and practical significance of this study will take the form of application of the analysis for improvement of the legal regulatory framework and grounding further research of social public procurement.

The objective of the study is to reveal the concept of social dimension of sustainable public procurement and its practical application features.

The object of the study is a social dimension of sustainable public procurement.

The following are the tasks of the research:

1. To define the concept of social aspect according to the conception of sustainable public procurement.

2. To review and assess the practices of implementation of social dimension of sustainable public procurement in some countries.

3. To investigate legal regulation of public procurement in the Republic of Lithuania and the situation in the field of application of social requirements.

4. To provide insights on the broader execution of socially oriented public procurement.

In the study, the theoretical research methods of systematic analysis, analysis of the scientific literature, linguistic, etc. have been applied. Systematic analysis method has been used for the examination of the public procurement interaction with other phenomena, identification of similar areas where the impact may be done. By virtue of scientific literature analysis, earlier studies are evaluated. Linguistic (grammatical) method has been applied to the interpretation of program documentation and regulatory formulas. For the empirical research, the following methods have been used: document analysis, statistical analysis, meta-analysis, summary, and other methods. Document analysis method 
has been applied for the evaluation of the current public procurement legislation, through identification of legal features and peculiarities of the research object. The paper also analyses quantitative data on social procurement in Lithuania. A meta-analysis method has been used for the analysis of the studies conducted by other researchers, and systemic thinking method has been applied to evaluate their results in order to make the findings of a new level. The summation method is invoked for making generalizations and conclusions.

\section{Social public procurement as a part of the concept of sustainable public procurement}

\subsection{Concept of sustainable public procurement}

In recent years, Lithuania and other countries of the world in science and practice focus on the concept of sustainable development, which for the first time on a global scale was formulated in 1987 in in the report "Our Common Future" presented in UN General Assembly session. The report states that "Sustainable Development is a development that meets the needs of the present without compromising the ability of future generations to meet their own needs". Stepby-step the sustainable development has been recognized as a major global development community's vision that raised this concept as an important policy objective (Liobikiene, Mandravičiūte 2011). At the level of the European Union, the sustainable development as a fundamental goal was first identified in 1997, signing the Treaty of Amsterdam. Since then, in all EU policy instruments the goal of sustainable development has been raised in all areas of public life. The renewed in 2006 EU Sustainable Development Strategy focuses on the following challenges: climate change and clean energy; sustainable transport; sustainable consumption and production; natural resource conservation and management; public health; social security, demography and migration; global poverty and sustainable development challenges. Thus, the concept of sustainable development that was born and developed within the framework of the $\mathrm{UN}$ and being the fundamental goal of the EU strategic documents, taking into account its versatility and need for systematic assessment, must be implemented in all areas of society life ensuring the balance of economic, social and environmental development.

In the economy of every state, acquisitions following the public procurement procedure compose a large part; this institute hides in itself the same power to influence the market, politics, law, economy, social environment, and internal environment of its organisation. Public procurement spending on average accounts for some $16 \%$ of expenditures of the EU's aggregate gross domestic product (GDP), though varying between 11 and 20\% for individual Member States (Engelbrekt 2012). According to the data of the Public
Procurement Office of Lithuania (Public Procurement office of Republic of Lithuania 2014), in 2013, the total amount used through the public procurement procedures (LTL $14,986.2$ million) is equivalent to almost 13 per cent of gross domestic product. The similar scale power can be used and is used for various other purposes. The world's scientists have repeatedly pointed this issue. Following T. MedinaArnaiz, "public procurement, as well as constituting a means of providing goods and services, also represents a powerful legal instrument available to contracting authorities to ensure compliance with secondary or non-commercial goals" (2010). McCrudden states that "governments widely use the power of public purchases in achieving additional social and environmental policy goals" (2004). Public procurement as one of the most effective elements of successful public policy is also named by the Lithuanian scientists $A$. Junevičius and S. Ereminaite (2010).

Instrumental application of public procurement is particularly challenging for the implementation of the sustainable development ideology. As the concept of sustainable development has taken root as the prevailing ideology of change, the requirements for the products needed for public administration entities activities and purchased mainly in the public procurement process, should also change and contribute to the implementation of the concept (Tvaronavičiene 2012). So it is necessary to talk about the sustainable public procurement as one of the tools having the potential, through the acquisitions of public administration, to bring more coherence with the environment (not limited to the environmental aspect, but more generally) to various areas of public life, and could stimulate dissemination of sustainable development principles among private sector entities seeking to be competitive in a changing market.

Today, both in national strategic documents, as well as legislation, and in scientific works the concept of sustainable procurement is often found. This concept, like the concept of sustainable development in general, began to be used within the framework of the UN activities. After the International Meeting of Experts in 2003 in Marrakesh, opportunities for public procurement policies to promote the innovation of environmentally friendly products and to achieve various social goals, were identified. The European Council in Gothenburg in 2001 adopted the European Union's Sustainable Development Strategy where decided to seek all-win solutions in all areas - economic, social and environmental; and procurement, which takes into account all of these three areas identified as sustainable procurement (European Commission 2001).

Sustainable public procurement both in international organisations' documents and national strategies, as well as in scientific works defined through the prism of the concept of sustainable development. Technology, Industry and 
Economics Division of the United Nations Environment Programme (UNEP) in the study "Sustainable public procurement in the system of the United Nations" provides the definition of sustainable public procurement: "the procurement shall be called sustainable when organisations use their own buying power to give a signal to the market in favour of sustainability and base their choice of goods and services on: economic considerations: best value for money, price, quality, availability, functionality; environmental aspects, i.e. green procurement: the impacts on the environment that the product and/or service has over its whole life-cycle, from cradle to grave; and social aspects: effects of purchasing decisions on issues such as poverty eradication, international equity in the distribution of resources, labour conditions, human rights (United Nations Environment programme (UNEP) 2004).

While analysing the work of scientists, national strategic documents and the documents of international organizations, the following definition of sustainable public procurement of Great Britain is often encountered, in 2005, it has announced its commitment to become a leading European country in sustainable procurement, the Government commissioned Sustainable Procurement Taskforce: "Sustainable Procurement is a process whereby organisations meet their needs for goods, services, works and utilities in a way that achieves value for money on a whole life basis in terms of generating benefits not only to the organisation, but also to society and the economy, whilst minimising damage to the environment" (DEFRA 2006). The same definition is used by Australia and New Zealand governments in common project, which aim is to strengthen sustainable procurement in the practice (APCC 2007). The above definition emphasizes the whole product life-term significance. The initial cost is not more important than the overall cost of the product, which is deduced through the whole life cycle in the organization (Tvaronavičiene 2012). Thus, besides the primary price of the product, the sustainable procurement "should consider the environmental, social and economic consequences of: design; non-renewable material use; manufacture and production methods; logistics; service delivery; use; operation; maintenance; reuse; recycling options; disposal; and suppliers' capabilities to address these consequences throughout the supply chain" (DEFRA 2006). The contracting authority driven by such incentives will acquire the most suitable products that will lead long-term costs to a minimum, together with not damaging the environment and serving the welfare purposes. Balance is crucial in this place. There is a very slight boundary between the usefulness for the organisation and usefulness for the society. The product is useful for organisation when goods, services or works are the most suitable for the everyday public function. Meanwhile, in this context, additional objectives shall be considered useful to the society: the social and environmental elements. The principle of the best money for value in the concept of sustainable public procurement serves as a certain fuse and ensure that the main purpose of the procurement is not smothered be extra ones. This is illustrated by the Australian and New Zealand definition in sustainable procurement guidelines: "Sustainable public procurement is sustainability principles' incorporation to purchasing decisions taking into account environmental and social factors and keeping value for money" (APCC 2007). So reckless pursuit of social and environmental objectives in the public procurement is not legitimate, because in this way the organisation can buy eco-friendly, socially desirable products that just do not fit for the purpose of the organisation. It is the "best value for money" principle as an integral part of the economic dimension of sustainable public procurement that protects the procurement process against certain abuses with the aim to purchase useless for the organisation but socially and environmentally friendly products.

In summary, it is necessary to emphasize that although the practice and science provide a number of different definitions of sustainable public procurement, however, core aspects are always the same: the best meet of the contracting authority's needs, the lowest total cost over the lifetime of the product, the sensitivity to the environment, and use social impact tools through acquisitions. In this context, it is possible to use the following generalised concept: sustainable public procurement is the acquisition most consistent with the needs of the contracting authority that is actively directed to ensure the economic, social and environmental balance (Tvaronavičienè 2012). In this case, isolation of the three elements of sustainable public procurement enables a deeper analysis of each of them, and the main object of study of the article is the social dimension of sustainable public procurement.

\subsection{Concept of social public procurement}

Social procurement in the most general sense can be defined as purchases for which not only the need for a rational use of funds in acquiring goods, works and services necessary for the contracting authority to meet its needs shall be taken into account, but also to focus on the positive social outcomes. Socially responsible public procurement concept is based on the basic assumption that public procurement should take into account one or more of the social aspects of employment, decent work, social and labour rights, social inclusion (including persons with disabilities), equal opportunities, accessibility, design for all, focusing on sustainability criteria, including ethical issues and wider voluntary corporate social responsibility in compliance with the requirements of the EU public procurement law (European Commission 2011). By agreeing to Shulten et al. (2012), it is possible 
to distinguish the following aspects of socially responsible public procurement in the EU:

1. Employment opportunities: to promote youth employment; to promote gender balance (eg., work/life balance, to fight against sectorial and occupational segregation, etc.); to promote employment opportunities for long-term unemployed and older workers; to promote employment opportunities for individuals from disadvantaged groups (such as migrants, ethnic minorities, religious minorities, low-educated workers, etc.); to promote employment opportunities for people with disabilities, providing them with favourable working environment.

2. Decent work: to ensure compliance with core labour standards, the right to a decent wage, health and safety; social dialogue; to provide an opportunity to learn; to ensure gender equality and non-discrimination principles, basic social security guarantees.

3. Social and labour rights: compliance with national laws and collective agreements which are compatible with the EU law; the principle of equal treatment for men and women, ensuring equal pay for work of equal value and promote gender equality; compliance with health and safety legislation; to ensure the implementation of the principle of non-discrimination on other grounds (age, disability, race, religion and belief, sexual orientation and so on).

4. Social integration and social enterprises: to provide an equal access to public procurement for social enterprises and non-profit organisations that employ people from disadvantaged groups; to promote a favourable working environment for people with disabilities.

5. Access for all: add the mandatory provisions to the technical specifications in order to ensure that public services, public buildings, public transport, public information, and information technology products and services, including online programs, accessibility for people with disabilities.

6. Procurement ethics: to ensure procurement ethics according to the technical specifications and terms of the contract.

7. Social responsibility of enterprises: while working with contractors to encourage introduction of voluntary corporate social responsibility values.

8. Protection of human rights and promotion of respect for human rights.

The above-listed issues, which should be consistent with public procurement, are called social, and present a broad view of the concept of the nature of such procurement. In evaluation of specific countries experience in the field of social procurement, it is clear that some of these requirements are implemented in public procurement with no view to make such a purchase social, but for compliance with other statutory provisions. For example, the design of public buildings necessary must conform to the technical building regulations containing requirements relating to the adaptation of buildings for reduced mobility persons. Another part of the requirements is implementable. The other part of the requirements, associated with the procurement object description and qualification requirements, depend on the will of the contracting authority and is only implementable upon the decision to carry out this kind of purchases. For instance, purchases from social enterprises. The third part of the requirements is related to business culture and legal consciousness of subjects thereof. For example, unethical public procurement, during which the statutory requirements are ignored, even though they have a social orientation, cannot be regarded as a desirable effect as they present a threat to the smooth functioning of the legal system.

\section{Social public procurement in the Republic of Lithuania}

\subsection{Legal background}

Given the fact that the concept of social procurement in Lithuanian law-making and science, in contrast to the world, is yet rarely used, this section will analyse the legislation of the Republic of Lithuania, which include provisions relating to the implementation of this concept as well as statistics showing the degree of realisation of these requirements. This study aims to determine the feasibility of social requirements in the procurements of the Republic of Lithuania.

For the first time, the concept of sustainable public procurement has been revealed in Lithuanian Public Procurement System Improvement and Development Strategy for 20092013 (Government of the Republic of Lithuania 2009). In this document, sustainable public procurement was described as a procurement subject to the requirements relating to the environmental, economic and social development. Notably, the Law on Public Procurement of the Republic of Lithuania, which is the main piece of legislation governing implementation of public procurement, omits the category of sustainable public procurement, but the legislature reveals the social dimension of public procurement providing opportunity for reserved purchases. In addition, this law contains provisions enabling contracting authorities to target their public procurement to social direction, for example, Part 4 of Article 24 of the Public Procurement Law, which sets out the requirements of the tender documents, states the following: "The contracting authority may lay down in contract documents special conditions for the performance of a contract relating to social and environmental requirements, provided that these are compatible 
with EU law" (Viešųų... 1996). This means that contracting authority can but not must apply social requirements by its own initiative. Nevertheless, this provision does not lack the passivity of the legislative bodies' side, because according to the quoted provision, the limits of application of social and environmental requirements are laid down in the $\mathrm{EU}$ legislation, without an obligation to the national legislature to create national legislation. This reticence is partly compensated by the Public Procurement Office. Director of the Public Procurement Office on June 30, 2010 by Order No. 1S-95 approved the Guidelines for Social Security Requirements for Public Procurement, which recommended contracting organisations to apply social requirements both for the procurement of a value in excess of the limits of international purchases, and to simplified procurement. Having examined this guidance document, we can distinguish three methods of social requirements inclusion in the procurement: voluntary contracting authority's decision, reservation of purchases following Article 13 of the Public Procurement Law, and mandatory procurement from social enterprises under Article 91 of the Public Procurement Law.

The first way is the decision of contracting authority based on its initiative and social responsibility to supplement the usual procurement documents by the social security requirements. While it is clear that the guidance for social security requirements for public procurement has been developed as an aid in the procurement from the companies mentioned in Articles 13 and 91 of the Public Procurement Law, it can serve in this case also, where the contracting authority carries out routine purchases and all providers are subject to the same social requirements. In this respect, the most important recommendation is laid down in Section 2, which presents and comments on the ways of social protection requirements inclusion in the contract documents. It is recommended to include such provisions either to supplier qualification requirements, or to the technical specifications or to the terms and conditions of the contract. However, this document is for guidance only, and in practice the social security requirements (except for reserved purchases and purchases from socially oriented companies) are usually not included to the procurement documents.

While examining the social dimension of sustainable development ideology regulations, the more appropriate is to discuss the contracting authorities' right and duty (in the case of simplified procurement) to reserve certain contracts to suppliers who employ disadvantaged persons. The already cited Part 4 of Article 24 of the Public Procurement Law provides for the opportunity to raise the social requirements in public procurement contracts. This provision is implemented by the Public Procurement Directives 2004/17/EC and 2004/18/EC, which provides contracting authorities with opportunities to set socially-oriented terms in public procurement provided that "such criteria are linked to the subject-matter of the contract, do not confer an unrestricted freedom of choice on the contracting entity, are expressly mentioned and comply with the fundamental principles mentioned in recital 9" (European Parliament 2004). Knowing that one of the fundamental principles of EU law on public procurement is non-discrimination, a systematic analysis of the cited provision, and the other EU legislation allows to conclude that socially-oriented requirements will not be considered discrimination of suppliers non-compliant thereto, if they are notified in advance, the requirements apply equally to all suppliers, the contracting authority makes an objective comparison of the offers received and they are related to the subject matter.

Contracting authority of the Republic of Lithuania under Article 13 of the Public Procurement Law is entitled to reserve a percentage of their purchases for social enterprises of persons with disabilities. The law states that the contracting authority may, in contract documents, set terms providing for such contracts to be executed exclusively by social enterprises of the disabled or specify that execution of such contracts shall be restricted to the framework of protected job programmes where most of the employees are disabled persons.

The contract documents, including a contract notice, must contain a reference to such contracts and the requirement to provide evidence that the supplier's undertaking complies with the requirements of this Article (a document issued by the competent authority or a statement approved by the supplier shall be presented). This provision applies to all contracts, and contracting authorities in both international purchases and simplified procurement can reserve a purchase for social enterprises of the disabled and so promote social integration of persons with disabilities. This provision in the view of simplified procurement, should be evaluated complexly together with Article 91 of the said law establishing the contracting authority's (with the exception of certain categories) the obligation "when conducting simplified procurement procedures, procure at least $5 \%$ of the total value of contracts awarded in simplified procurement procedures from social enterprises of the disabled, social enterprises, the enterprises in which $50 \%$ of the employees are inmates of penitentiary institutions serving the sentence of arrest, fixed-term imprisonment or the sentence of life imprisonment or the enterprises in which health care institutions have an interest, if at least $50 \%$ of the employees are occupational therapy patients for the purpose of procurement of supplies manufactured, services provided or works performed by them or implementation of protected job programmes where most of the employees are disabled persons, with the exception of the cases when these institutions and enterprises do not manufacture supplies, do not provide services or do not perform works for the 
contracting authority". In the sake of clarity, such purchase can be called procurement from socially oriented companies, because social enterprise category used until now is too narrow, as it covers only a part of the operators who employ disadvantaged groups. Thus, in the case of simplified procurement, the range of providers that can participate in reserved procurement is extended, not only limited to social enterprise for people with disabilities. The ideological foundation of these provisions is formed from certain labour market privileges for the companies employing supported people. This is not a novelty in Lithuanian public procurement legislation, as appropriate opportunities for people with disabilities have been provided for even in the first version of the Public Procurement Law, adopted in 1996. However, a kind of new tone to promote socially oriented reserved procurement was awarded in response to the $\mathrm{EU}$ procurement directives, in particular the implementation of the requirements set in the 2004/17/EC and 2004/18/EC directives to reserve participation in public procurement to organisations of persons with disabilities. Reserved purchases, of course, is a significant step in achieving social goals, but these acquisitions are focused on the benefit of businesses employing disadvantaged members of society, while the wider general direction of social requirements in public procurement towards the social dimension of the sustainable development concept should pay attention of all market participants and would lead to a broader supplier involvement in positive social activities. Socially responsible procurement, according to the authors, should not be limited to reserved purchases or procurement from social enterprises, because these are only two ways to include the social dimension of sustainable development to procurement activity. It is necessary to find ways to encourage contracting authorities to apply in its own initiative social requirements, in accordance with part 4 of Article 24 of the Public Procurement Law.

Value of simplified procurement from enterprises, millions litas

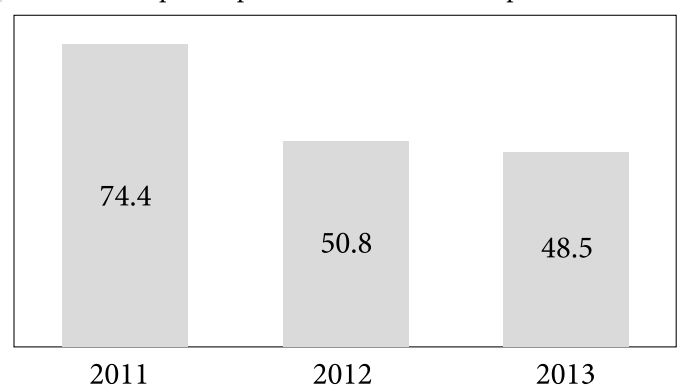

Fig. 1. Value of simplified procurement from social enterprises in 2011-2013, LTL mill. The information is prepared following the data of public procurement (annual) reports accumulated in the Central Information System of Public Procurement (Public Procurement office of Republic of Lithuania 2012, 2013, 2014)
It should be noted that the new public procurement Directives 2014/24/EU and 2014/25/EU give considerable attention to social procurement. Member States are obliged to take appropriate measures to ensure that economic operators perform public contracts complying with the applicable obligations in environmental, social and labour law fields. Also, the possibility of reserved purchase is retained and the range of entities that can participate in the procurement is extended (not limited to social enterprise of people with disabilities).

Upon examination of core manifestations of the dissemination of social dimension of sustainable development ideology in public procurement system of the Republic of Lithuania, it can be concluded that the public policy of our state basically uses the institute in question as an instrument to achieve social goals. On the other hand, it is clear that a broader application of social requirements in public procurement depends on the will of the contracting authorities. Therefore assessment of other countries' experience in this area suggests to Lithuania to speed up efforts to achieve a more efficient application of social aspects in the public procurement. The need for these measures is illustrated by the procurement statistics in Lithuania.

\subsection{Statistics of public procurement from the social entities in the Republic of Lithuania}

The evaluation of the data of (annual) reports accumulated in the Central Public Procurement Information System shows (Fig. 1) that value of simplified procurement from social enterprises is very low compared to the total value of the simplified public procurement:

It should be noted that in 2011 the total value of procurement was LTL 4.43 billion, so purchases from social enterprises accounted for only about 1.7 per cent, respectively, in 2012 it made 1.1 per cent (the total value of purchases LTL 4.46 billion), in 2013 the figure was 1.03 per cent (the total value of LTL 4.69 billion). Paradoxically, the total value of public procurement during the period grew, and the value of social purchases declined.

The analysis of the data for the period of contracting organisations carrying out social procurement, it is clear that the number is a little variable: 589 contracting authorities in 2011, 573 in 2012 and 584 in 2013. For comparison it is necessary to recall that according to the PPO data now in Lithuania public procurement must be carried out by more than 7,500 contracting authorities. These data imply the assumption that only a small part of the contracting authorities carry out social procurement, and the stable number thereof suggests that this may be largely the same organizations. This indicates about the lack of promotion of social procurement.

76 social enterprises have announced about goods manufactured, services provided and works performed in Central Public Procurement Information System. Consideration 
shall be given to the fact that Lithuanian Labour Exchange (2014) has currently given social status to 137 companies. Thus Figure 2 identifies, that in 2013 , about 56 per cent social enterprises were interested in participating in public procurement, and 40 per cent participated therein. The Figure 2 shows the activity of procurement during the period.

The data in Figure 2 show that a large part of the social enterprise are involved in the procurement. In 2011 and 2012, 50 social enterprises participated in public procurement tenders ( 43 won), in 2013, 53 social enterprises participated (47 won).

The number of procurements where in 2011-2013 social enterprises participated is much higher:

According Figure 3, in 2011, social enterprises participated in 726 purchases (won 401), in 2012 - in 742 (won 354), in 2013 - in 769 (won 332). So, it can be concluded, that activity of at least a part of social enterprises in general mainly depend on public procurement as a tool for implementation of social policy.

The analysis of the practical implementation of the provisions concerning mandatory public purchases from social enterprises of Article 91 of the Public Procurement Law shows that such purchases represent only a very small part of the simplified public procurement: In 2011, it made 1.6 per cent, in 2012 - 1,1 per cent, in 2013 the figure was 1 per cent of total simplified public procurement value.

It is clearly seen from the statistical data in Figure 4 that the number of social purchases being implemented in Lithuania does not become closer to the 5 per cent limit set by the legislator. This signals about ineffectiveness of the legal rule.

Analysis by the purchase objects shows that the main part of the procurement, where social enterprises won was carried out in order to purchase furniture, cleaning, engineering, and printing services.

The data show that a large part of social procurement is targeted to the service sector. However, according to the data of the Public Procurement Office, the analysis of procurement by type of the object, in 2012-2013, mostly supplies had been purchased from social enterprises ( 46.7 per cent, and 38.4 per cent), while in 2011, mainly the works were acquired -42.9 per cent.

In summary, upon analysis of statistical data on the performance of social procurement in the Republic of Lithuania for 2011-2013, it is necessary to draw attention to fact that the value of simplified procurement from socially-oriented enterprise compared to the total value of the simplified public procurement is very small and accounted for only 1.7 to 1.03 per cent of the total value of such contracts in 2011-2013. It should be noted that only a small part of contracting authorities carry out social procurement, and the stable number suggests that this may be largely the same organisations, which shows the lack of promotion of procurement of this kind. The main conclusion that can be made from the statistical data is
Number of social enterprises participated in public purchases Number of social enterprises won in public purchases

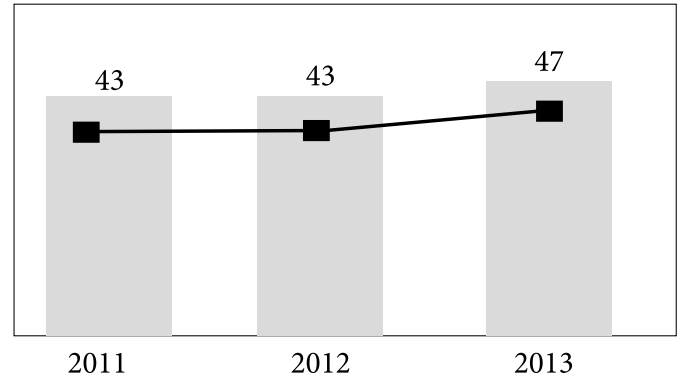

Fig. 2. Number of social enterprises participated/won in public purchases in 2011-2013. The information is prepared following the data of public procurement (annual) reports accumulated in the Central Information System of Public Procurement (Public Procurement Office of Republic of Lithuania 2014, 2013, 2012)

Number of public procurement where social enterprises participated Number of public procurement where social enterprises won

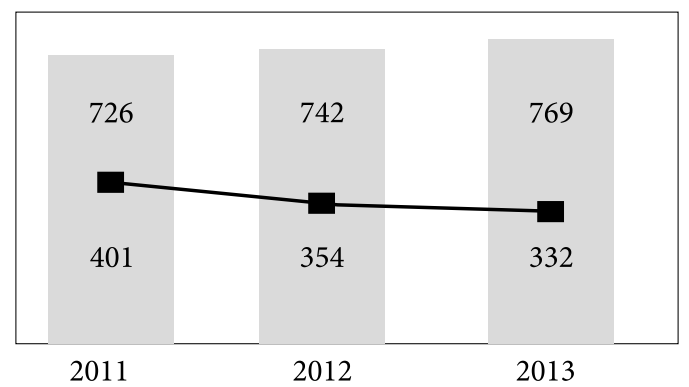

Fig. 3. Number of public procurement where social enterprises participated/won in 2011-2013. The information is prepared following the data of public procurement (annual) reports accumulated in the Central Information System of Public Procurement (Public Procurement Office of Republic of Lithuania 2014, 2013, 2012)

Value of simplified public procurement, mlrd. litas

Value of procurements from social enterprises and other supported entities, per cent

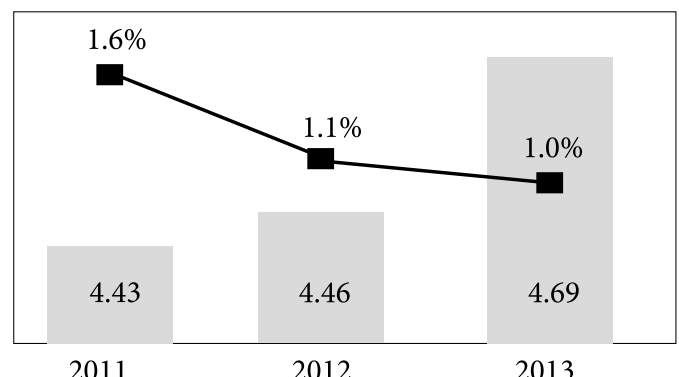

Fig. 4. Value of simplified public procurements in 2011-2013. The information is prepared following the data of public procurement (annual) reports accumulated in the Central Information System of Public Procurement (Public Procurement Office of Republic of Lithuania 2014, 2013, 2012) 
that the number of social purchases being implemented in Lithuania does not become closer to the 5 per cent limit set by the legislator. This signals about ineffectiveness of the legal rule.

\subsection{Main risks of social public procurement and problems of its implementation in the Republic of Lithuania}

Benefits of socially responsible public procurement are undeniable. Firstly, they can assist in meeting national and international commitments in the field of social policy. Traditional incentive mechanism of social justice and social cohesion poses many challenges to national governments, and socially responsible public procurement can be seen as one of the instruments for coordination of social and economic issues, to both public and private sector benefit purposes. Secondly, socially responsible public procurement make preconditions to develop socially useful supplies and services markets, for example, information technology accessible to people with disabilities can bring a better quality and more affordable goods and services to the market. Third, socially responsible public procurement represents the state position on the society's values and interests, as well as meets the expectations of the public, showing that the public authorities are socially responsible for their behaviour. This behaviour creates a synergistic relationship with different social groups, facilitates their integration and, therefore, more efficient operation of the market. Fourth, socially responsible public procurement helps to ensure a more efficient management of public expenditure, as they can reduce direct costs of social protection (European Commission 2011).

Despite these socially responsible public procurement advantages, it should be noted that in each case the contracting authority needs to achieve the equilibrium of public procurement efficiency and social orientation. In this context, it is appropriate to examine the major threats related to social requirements in the application of public procurement.

In practice, public procurement is a particularly sensitive area for pathological behaviour. According to A. D'Souza and D. Kaufmann (2013), media reports and anecdotal evidence suggest that in environments characterized by a lack of transparency and high monitoring costs, bribery is commonplace and often plays a critical role in determining which firm wins a public contract and how contracts are executed. These authors, analysing forms of corruption activities in public purchases, state that "data reveal that a large proportion of managers across the globe admit that "firms like theirs" pay illicit payments in order to secure government contracts. On average, approximately $32 \%$ of managers' report that firms like theirs bribe to secure a government contract; this percentage ranges from $13 \%$ of firms based in high income OECD countries to $32 \%$ in middle-income countries and 50\% in low-income countries. Identified "charges" in terms of procurement over the globe draw attention to the importance of the problem, and requires to consider not only planned benefits, but also the threat of any possible reverse effect, i.e. the preconditions for the emergence of fraudulent behaviour, when talking about an instrumental purpose of public procurement.

Thus, socially responsible public procurement benefits to society beyond doubt, but it is clear that in practice there may appear threats associated with the application of social requirements. In the face of such threats, it is observed that usually there are no scientists promoting socially-oriented public procurement by research object. In authors' opinion, in practice, statutory instruments promoting social procurement are often used, in particular, not to benefit the public, but to create an advantage for certain enterprises. This aspect is even discussed in press (for example, Ekonomika 2011), what shows its importance. Several directions of abuse of social considerations in public procurement are to be identified. In particular, it is a case where a social enterprise is set up fictitiously just to win reserved public procurement. This threat should be identified as one of the least harmful, because in order to meet the requirements of Social Company Law and acquire the status of social company, the company must meet a number of requirements that cannot be realised otherwise than by creating jobs. According to Part 1 of Article 3 of the law, social enterprise must employ at least 40 per cent from the annual average number of employees of people who have lost their professional and general ability to work, economically inactive, unable to compete on equal terms in the labour market (according to the target groups provided for in the law). In any event, in order to take advantage of the benefits offered to social enterprises, it is necessary to create jobs for members of disadvantaged groups; it naturally has a socially positive orientation.

On the other hand, the contracting authority may also act in bad faith, not to comply with free market and fair competition, to create an uneven playing field for competitors, for example, using the vendor-specific advantages, which does not have other suppliers in the market offering a similar product or service. Vilnius Municipality in 2011 (Balsas.lt 2011, Delfi 2014) raised a proposal to set mandatory social qualification criteria relating to the requirement of businesses to pay their employees no less than the average wage; the proposal was quite controversially assessed. Of course, such a socially-oriented criterion for public procurement has the potential to raise the overall country's wages level, but there are also a number of negative consequences of the introduction of such a requirement. For example, artificial wage increase not taking into account the company's financial capacity to pay such wages can lead to financial difficulties for a significant proportion of companies, which upon failing to reach its target, i.e. not getting awarded the contract, can be followed by negative consequences. Another threat is that the payment of 
average wage naturally raises the costs of services provided and at the same time increases the price of the proposal for public procurement. Contracting authorities imposed any such or similar qualification criteria should be ready to pay more for the purchase of goods, services or works. Thus, the two competing interests encounter: the overall increase in state welfare versus less rational use of taxpayers' money. Contracting authorities must seek a balance between these two objectives, which in narrow sense is often not convenient to the certain contracting authority. It is obvious that this type of requirements cannot be binding, as they lead to a lot of negative consequences. In some cases, when contracting authority sees the meaningfulness of such requirement application and has the financial capacity to cover the increase in price of goods, services and works; such requirement should be encouraged. The essential condition for the application of this kind of requirement is consistency, because a single type of requirement raised in a particular tender and unexpectedly to entities operating in the segment are more likely to mean manifestation of acts of corruption, than the tendency of public procurement to solve certain social problems.

In case of socially oriented procurement, the problem of range and quality of goods, services or works remains sensitive. Social enterprises are not always able to offer a large variety of goods and services, sometimes offered goods or services do not meet the quality requirements. Faced with such a problem, the option is to choose whether to purchase supplies, services or works of inferior quality or not fully complying with the technical requirements of the contracting authority and implement a social purchase, or to buy in the normal way and get the most suitable products. This situation is mainly determined by the fact that very few social purchases are carried out, so social companies do not have enough orders, and it also happens due to their inability to invest in the professional development of their staff or process improvement. On the other hand, positive discrimination, which usually describes a situation where due to the social incentives for certain entities the state provides advantages in comparison with other actors in the market, is an inevitable part of the social policy, which the Procurement Institute can and must assist to.

As already mentioned above, the law of the Republic of Lithuania establishes a mandatory provision that obliges contracting authorities to award at least 5 per cent of simplified procurement to social enterprises. In this provision, the number of social procurement expressed as a percentage according to the statistical data is clearly not achievable. This presupposes that the provision is not viable, and in the absence of a mechanism to encourage contracting authorities to follow up and achieve the identified orientation of procurement to social enterprises it is not possible to achieve its efficiency. This provision is open to criticism on several grounds. First of all, it guides contracting authorities in very narrow way, as brings socially oriented procurement basically just to the procurement from social enterprises. As social enterprises operating on the market are not able to offer a wide range of high-quality supplies, services and works, contracting authorities are not interested to supplement purchases for which social enterprises cannot offer anything, with social aspect and use the pretext of impossibility to apply the provision under question, i.e. option not to award some contracts to social enterprises as they do not offer required production. This problem could be corrected if the requirement of 5 per cent considers not purchasing from the social companies, but in general, the social procurement. The limit could even be enlarged to 10 or 15 per cent. In this way, the contracting authority could choose the most acceptable opportunity to supplement their procurement activity with social terms provided for in the Public Procurement Law. Its second deficiency is the lack of measures to encourage/enforce contracting authorities to carry out socially-oriented purchases. The present provision of part 1 Article 91 contains a reservation "with the exception of the cases when these institutions and enterprises do not manufacture supplies, do not provide services or do not perform works for the contracting authority", which allows justifying the failure to comply with the obligation in an absolute majority of cases. This situation should be changed by creating implementation mechanism for the provision.

In summary, it should be noted that, in any event, best value for money should be regarded as the optimum combination of whole life cost and quality to meet the end user's requirements. Social aspects are always encouraged, but they should not outdo procurement effectiveness. It can be concluded that a balance between social orientation of public purchases and effectiveness thereof is necessary for the purpose of purchasing actually needed by the contracting authority goodies rationally using the resources; and if possible, at the same time creating a positive social effect. In order to successfully implement the current social procurement encouraging system in the Republic of Lithuania it is recommended to evaluate the ability to set the requirement to achieve certain percentage of all public purchases value not only for procurement from social enterprises, but for social purchases in a broad sense, i.e. including reserved purchases from social enterprises for disabled people as well as purchases with social aspects included in qualification requirements and technical specification.

\section{Good practices of social public procurement realization}

In the global practice at different levels (international, national, regional or local), there is a number of socially oriented procurement best practices, a brief analysis thereof 
will help to broaden horizons and realise that social orientation of procurement is compatible with the rational use of funds and the purchase of eligible products. It should be noted, that the EU public procurement legislation, in particular the new directives, pays considerable attention to the social aspect, and the Member States are expected to set the special measures for its implementation. According to the Directive 2014/24/EU, "with a view to an appropriate integration of environmental, social and labour requirements into public procurement procedures it is of particular importance that Member States and contracting authorities take relevant measures to ensure compliance with obligations in the fields of environmental, social and labour law that apply at the place where the works are executed or the services provided and result from laws, regulations, decrees and decisions, at both national and Union level, as well as from collective agreements, provided that such rules, and their application, comply with Union law."

Perhaps the most common means of promoting the broader sustainability criteria of public procurement is setting a target value of contracts size (which is implemented not only in Lithuania, but also in Belgium, Denmark, Finland, Italy, etc.), various activities related to the publicity of these ideas (Bulgaria, Austria, Cyprus, Czech Republic, etc.), and strategic plans (basically all the European Union Member States). In some countries, those standard sustainable procurement (including social) incentives are supplemented by real practice, which has already achieved results that can be seen as yielding benefits (Alejandre et al. 2012).

After assessing the best practices described in various publications, it can be divided generally into several groups. First of all, it should be noted that a number of organisations in the world prior to their purchasing make themselves familiar with socially oriented business activities in the market and are looking for ways to effectively use the goods, services or works produced for the needs of contracting authority. Another example of good practice is assistance to the socially-oriented enterprises in developing their competencies to participate in public procurement in general. For example, in order to facilitate access to public procurement opportunities for small and medium-sized enterprises, social, economic and voluntary organisations working with social groups of non-favourable conditions, the Swedish Social Insurance Agency includes those groups in their initial study of public procurement to a clearer understanding of their specific problems in preparing procurement documents for tenders. In this way, Swedish Social Insurance Agency assesses risks of not meeting social standards at the beginning of the procurement process (European Commission 2011). Another example of the same kind of aid is the Danish National Procurement Office. Social aspects of public procurement is one of the topics that the Danish National Procurement Service examines in its analysis of the market before the publication of the procurement of each tender. This office provides training programs and organises seminars for all providers. It tries to simplify the procurement documentation for small and medium-sized enterprises to have sufficient resources to develop a competitive proposal (European Commission 2011). Very often training the competence to participate in public procurement is very important because only properly arranged tenders and timely defence of possibly damaged interests form preconditions for successful participation.

In Europe, there are also examples where the social dimension of public procurement becomes imperative, and all or at least part of the contracting authorities must be perform public purchases in accordance with social requirements. For example, an experience of the Spanish Basque country is interesting: its Government has published binding instructions on the inclusion of social criteria in their administration's and authorities' public procurement procedures. The document details assessment and monitoring of procurement contracts, recommendations for technical specifications, procurement contracts award criteria, performance conditions, such as staff performing the contract must include a percentage of disadvantaged individuals, such as the unemployed, people with disabilities, longunemployed women aged more than thirty years, domestic violence victims, mentally ill, unemployed single parents, immigrants unemployed for at least six months, the longterm unemployed (more than one year) or unemployed young people (European Commission 2011).

Another example of good practice, already mentioned in this article, is consolidation of requirements of other laws, not related to procurement, which is indirectly implementable in practice through public procurement procedures. The above mentioned requirement of technical regulations of construction for the design of public buildings to provide for public access to the people with reduced mobility, can be supplemented with various types of non-discrimination requirements. For example, in the UK, in April 2007 the adoption of the Equality Act set an obligation to public sector to respect the principle of gender equality, which includes the requirement for the same work, and to ensure equal pay. The gender equality duty has prompted many public initiatives and private sector contractors to change their working conditions applicable to the procurement context (European Commission 2011). However, anchoring of such requirements in legislation related to public procurement also requires exclusive attention of contracting authority's professionals, since it is necessary to develop a system to verify compliance thereto while assessing the proposals.

Another example of how to bind suppliers in procurement and the contract to be socially responsible is the call to sign the specific codes of conduct. In this case, the Code of Conduct is a list of commitments that the bidders are asked 
to agree to as part of their tender submission. Non-agreement automatically leads to the exclusion of the bidder (Santos et al. 2012). Socially responsible business rules usually defined in such codes mainly relate to a decent wage, promoting the involvement of vulnerable groups, non-discrimination and non-exhaustion of employees and the like. Such practices are used in Swedish municipalities on a quite wide range (Santos et al. 2012). Given that signing of certain rules does not automatically make suppliers orienting execution of the contract towards the requirements, municipalities use extensive monitoring system, and any violations of socially oriented rules signed together with a proposal create preconditions for termination of a contract or claim of penalties under the contract.

To summarise the good practices of socially-oriented procurement in the EU countries, the following several key incentives can be distinguished: encouraging contracting authorities to become familiar with products offered by the socially oriented companies before purchasing; application of a variety of assistance measures in developing competencies of such companies to participate in public procurement; setting the imperative provisions to apply social requirements for certain organisations; controlling the compliance with the requirements set out in other legal acts in respect of public procurement contracts; and application of codes of conduct of socially responsible behaviour for suppliers. The abundance and variety of tools allow choosing social procurement incentives effective and appropriate to a particular country, not limited to declarative provisions that nobody cares to be implemented in practice.

\section{Conclusions and recommendations}

Social public purchases as a part of the concept of sustainable public procurement may be defined as public procurement where the contracting authority applies additional socially oriented requirements. The Law on Public Procurement of the Republic of Lithuania provides three ways for contracting authority to supplement their purchases with a social dimension: the right to reserve contracts for social enterprises for disabled people; the duty to carry out at least 5percent of the total value of simplified procurement from social enterprises for disabled people, social enterprises or companies employing more than 50 percent of the convicts; and the companies whose members are health care institutions and at least 50 percent of patients work thereat for therapy; and the right to supplement the terms of the purchase by qualification or technical requirements of social nature. It is evident from the statistical data related to the simplified procurement procedure from socially-oriented enterprises that the numerical aim set by the law has not been achieved for several years; and purchases from such enterprises are mostly episodic and have not yet become an integral part of the public procurement policy of contracting authorities. The statistics implies the assumption that only a small part of the contracting authorities carry out social procurement, and the stable number thereof suggests that this may be largely the same organizations. This signals on the lack of promotion of social procurement and little publicity for the need to carry them out. However, an indiscriminate orientation of procurement to the social direction cannot be seen as aspirational as it does not guarantee the optimal solution in the price-quality ratio. Notably, in practice, an application of social public procurement may have both positive and negative consequences. In order to achieve a balance between these two dimensions in public procurement process, it is necessary for contracting authorities to seek balance between social orientation of public purchases and effectiveness thereof for the purpose of purchasing actually needed by the contracting authority goodies rationally using the resources; and if possible, at the same time creating a positive social effect. In order to successfully implement the current social procurement encouraging system in the Republic of Lithuania it is recommended to evaluate the ability to set the requirement to achieve certain percentage of all public purchases value not only for procurement from social enterprises, but for social purchases in a broad sense, i.e. including reserved purchases from social enterprises for disabled people as well as purchases with social aspects included in qualification requirements and technical specification. It is also necessary to develop a mechanism for identifying measures to ensure the implementation of the provision under analysis. Taking into account the best foreign practice it is also recommended to consider taking specific measures both in encouraging contracting authorities to apply the social requirements in public procurement and developing socially-oriented business competencies to participate in such proceedings.

Social public procurement (as well as in general public procurement) is a field of research which requires interdisciplinary approach. Designing future research implications in this field it is recommended to pay attention towards separate aspects of the problem as the need of application of certain stimulation measures (both managerial and legal), requirements for social enterprises and its implementation as well as in managerial level analysing in general demand and supply issues in this section of market.

\section{References}

Alejandre, E.; Traspaderne, A.; Ortiz de Elgea, A. 2010. Best practice on green or sustainable public procurement and new guidelines [online], [cited 13 August 2014]. Available from Internet: http:// www.openhouse-fp7.eu/documents/deliverables

Australian Procurement and Construction Council. 2007. Australian and New Zealand Government framework for sustainable procurement [online], [cited 13 August 2014]. Available from Internet: http://www.apcc.gov.au/SitePages/ Procurement.aspx. 
Balsas.lt. 2011. A. Zuokas: kiemsargio alga „popieriuje“ turi būti ne mažesnè kaip $1500 \mathrm{Lt}$ [A.Zuokas: the salary of watchman can not be lower than 1500 Litas] [online], [cited 13 August 2014]. Available from Internet: http://www.balsas.lt/naujiena/551308/www.balsas.lt/naujiena/615224/\%22mailto:info@ balsas.lt $\% 22$

Brammer, S.; Walker, H. 2007. Sustainable procurement practise in the public sector: an international comparative study [online], [cited 13 August 2014]. Available from Internet: http://www. bath.ac.uk/management/ research/pdf/2007-16.pdf

Delfi 2014. A. Zuokas. Valstybè neturi pirkti paslaugu iš įmonių, kurios moka minimaly atlyginima [A. Zuokas. Government cannot buy services from entities which pays minimal salaries] [online], [cited 13 August 2014]. Available from Internet: http://www.delfi.lt/news/ringas/politics/a-zuokas-valstybeneturi-pirkti-paslaugu-is-imoniu-kurios-moka-minimalu-atlyginima.d?id=64025692\#ixzz3Iyix3etS

Department for Environment Food and Rural Affairs. 2006. Procuring the Future: Sustainable Procurement National Action Plan Recommendations from the Sustainable Procurement Task Force [online], [cited 13 August 2014]. Available from: http:// www.defra.gov.uk/publications/files/pb11710-procuring-thefuture-060607.pdf

Directive 2004/17/EC, coordinating the procurement procedures of entities operating in the water, energy, transport and postal services sectors. European Parliament and Council.

Directive 2004/18/EC on the coordination of procedures for the award of public works contracts, public supply contracts and public service contracts. European Parliament and Council.

Directive 2014/24/EU on public procurement and repealing Directive 2004/18/EC. European Parliament and Council.

Directive 2014/25/EU on procurement by entities operating in the water, energy, transport and postal services sectors and repealing Directive 2004/17/EC. European Parliament and Council.

D’Souza, A.; Kaufmann, D. 2013. Who bribes in public contracting and why: worldwide evidence from firms, Economics of Governance 14(4): 333-367. http://dx.doi.org/10.1007/s10101-013-0130-5

Ekonomika.lt. 2014. Aiškinsis dèl galimo piktnaudžiavimo socialiniu imoniu statusu [Will explore the potential for abuse of the social enterprise status] [online], [cited 13 August 2014]. Available from Internet: http://www.ekonomika.lt/naujiena/ aiskinsis-del-galimo-piktnaudziavimo-socialiniu-imoniustatusu-9484.html

Engelbrekt, K. 2011. EU Enlargement and the emboldening of institutional integrity in Central and Eastern Europe: the tough test of public procurement, European Law Journal 17(2): 230-251. http://dx.doi.org/10.1111/j.1468-0386.2010.00546.x

European Commission. 2001. An European Union Strategy for Sustainable Development [online], [cited 13 September 2014]. Available from Internet: http://eur-lex.europa.eu/legal-content/ EN/ALL/FLX_SESSIONID=fPnzJk5f3blhlfL4XXkh4QnQS fvkJwwgf9sCq7zKlNjqZfWNLDqD!1305838705?uri=CELE X:52001DC0264

European Commission. 2011. Buying social a guide to taking account of social considerations in public procurement [online], [cited 13 August 2014]. Available from Internet: http:// ec.europa.eu/social $/$ main.jsp? catId=738\&langId=lt\&pubId= 606\&furtherPubs=yes
Governement of Republic of Lithuania 2009. Lietuvos viešuju pirkimu sistemos tobulinimo ir pletros 2009-2013 metu strategija [Strategy on development for system of Public Procurement in Lithuania for 2009-2013]. Governement of Republic of Lithuania.

Junevičius, A.; Ereminaitė, S. 2010. E. viešųjų pirkimų tvarkos optimizavimo ir efektyvumo dindimo galimybès [The possibilites of increasing of optimization and effectiveness of e-public procurement], Organizacijų vadyba: sisteminiai tyrimai [Management of organizations: sistematic research] 54: 67-84.

Liobikienè, G.; Mandravičiūtè, J. 2011. Achievements of Lithuanian sustainable development during the integration process into the European Union, Technological and Economic Development of Economy 17(1): 62-73.

http://dx.doi.org/10.3846/13928619.2011.554000

Lithuanian Labour Exchange 2014. List of Social Enterprises [online], [cited 13 August 2014]. Available from Internet: http:// www.ldb.lt/Informacija/PaslaugosDarbdaviams/Puslapiai/ soc_imones_sarasas.aspx.

McCrudden, Ch, 2004. Using public procurement to achieve social outcomes, National Resources Forum 24: 257-267.

McCruden, Ch. 2007. Corporate social responsibility and public procurement, Oxford Legal Studies Research Paper No. 9/2006.

Medina-Arnaiz, T. 2010. Integrating gender equality in public procurement: the Spanish case, Journal of Public Procurement 10(4): 541-563.

Palidauskaitė, J.; Ereminaitè, S. 2010. Korupcija viešuosiuose pirkimuose: nuo teorinès apibrèžties iki atvejo studijos [Corruption in public procurement: from theoretical approach to case study], Viešoji politika ir administravimas [Public policy and administration] 32: 74-84.

Public Procurement Office of Republic of Lithuania. 2010. Socialines apsaugos reikalavimu taikymo viešuosiuose pirkimuose rekomendacijos [Recomendations on Aplication of Social Requirements In Public Procurement] [online]. Public Procurement Office of Republic of Lithuania [cited 13 September 2014]. Available from Internet: http://www3.lrs.lt/pls/inter3/ dokpaieska.showdoc_l?p_id=378083\&p_query=\&p_tr2=

Public Procurement Office of Republic of Lithuania. 2012. Annual report 2011 [online], [cited 13 August 2014]. Available from Internet: http://www.vpt.lt/rtmp8/dtd/index. php?pid=121189211065\&lan=LT

Public Procurement Office of Republic of Lithuania. 2013. Annual report 2012 [online], [cited 13 August 2014]. Available from Internet: http://www.vpt.lt/rtmp8/dtd/index. php?pid=121189211065\&lan=LT

Public Procurement Office of Republic of Lithuania. 2014. Annual report 2013 [online], [cited 13 August 2014]. Available from Internet: http://www.vpt.lt/rtmp8/dtd/index. php?pid=121189211065\&lan=LT

Santos, A. T.; Hooper, M.; Evans, E.; Dannenmaier, V. 2012. Useful guidance and tools for socially responsible public procurement [online], [cited 13 August 2014]. Available from Internet: http://www.landmark-project.eu/en/guidance-tools/

Soloveičikas, D. 2009. Public procurement in Lithuania: the ongoing development, European Public Private Partnership Law Review 2: 104-116. 
Shulten, T.; Alsos, K.; Burgess, P.; Pederen, K. 2012. Pay and other social clauses in European public procurement: an overview on regulation and practices with a focus on Denmark, Germany, Norway, Switzerland and the United Kingdom [online]. European Federation on Public Service Unions [cited 13 August 2014]. Available from Internet: http://www.epsu.org/IMG/ pdf/EPSU_Report_final.pdf

Thai, K. V. 2011. Public Procurement Re-examined, Journal of Public Procurement 1(1): 9-50.

The European Union Sustainable Development Strategy. 2006. The European Council.

Tvaronavičienè, A. 2012. Viešieji pirkimai kaip vienas iš darniojo vystymosi koncepcijos igyvendinimo instrumentų
[Possibilities to use Public Procurement as one of the instruments of sustainable development in Republic of Lithuania], Business: Theory and Practice 13(3): 197-207.

United Nations environment programme. 2004. A Guide on sustainable procurement in the UN system [online], [cited 13 August 2014]. Available from Internet: http://www. unep.org/resourceefficiency/Home/Society/SustainableUN/ReducingtheUNsImpact/Procurement/Guidelines/ tabid/101228/Default.aspx

Viešujų pirkimų įstatymas [Law on Public Procurement]. 1996. Parliament of Republic of Lithuania.

Virginijus KANAPINSKAS. Doctor of Social sciences (law), lecturer of Mykolas Romeris University Institute of Constitutional and Administrative Law, Member of Chief Official Ethics Commission. Research interests: public service, public procurement, energy law.

Žydrūnas PLYTNIKAS. Lecturer of Mykolas Romeris University Institute of Constitutional and Administrative Law, Former Director of Public Procurement Office. Research interests: public procurement.

Agnė TVARONAVIČIENĖ. Lecturer of Mykolas Romeris University Institute of Communication and Mediation, PhD student of Mykolas Romeris University Institute of Constitutional and Administrative Law, Chairperson of Lithuanian Arbitration Court. Research interests: public procurement, alternative dispute resolution. 